\title{
全視野における明るさ知覚特性
}

\author{
正会員 綿貫 將（株式会社日建設計 当時芝浦工業大学）正会員 高橋 宏（神奈川工科大学） \\ 専門会員 入倉 隆 (芝浦工業大学)
}

\section{Brightness Perception Throughout the Entire Visual Field}

Member Tasuku Watanuki (Nikken Sekkei Ltd), Member Hiroshi Takahashi (Kanagawa Institute of Technology) and Fellow Member Takashi Irikura (Shibaura Institute of Technology)

\begin{abstract}
Recently, research has been done from various directions to evaluate the brightness of spaces. However, no studies have been conducted regarding quantitative measurements of the brightness at different positions in a visual field. That is, a model for evaluating the brightness of spaces and lighting design techniques have not been considered much regarding the brightness at different positions in the visual field. Therefore, in this study, the sensitivity to brightness at different positions in the visual field was investigated in order to quantify brightness perception throughout the entire visual field. The experimental results show the tendency for $\mathrm{Lm} / \mathrm{Lt}$ rises as the visual angle increases. Moreover, they show the $\mathrm{Lm} / \mathrm{Lt}$ in the vertical lower direction is higher than that in other directions, especially at 20 degrees or more.
\end{abstract}

KEYWORDS : brightness, brightness sensitivity, entire visual field, luminance

\section{1. まえがき}

今日，光環境の新たな設計指標として，人が空間全体から感じ る明るさの感覚量である「空間の明るさ感」が期待されている. 従来の設計指標である水平面照度では，人が空間全体から感じる 明るさを定量的に評価することができないことに加えて，省エネ 性に欠ける点が指摘されていた。この課題解決策として考えられ ているのが, 空間の明るさ感を設計指標に取り入れることである. 明るさ感に関する研究は, 視覚生理・視覚心理の視点から様々な 研究が行われている。局所的な明るさ知覚の研究として, Stevens ${ }^{12)}$ はマグニチュード推定法を用いた実験により，明るさ 感と輝度のべき法則を示し, これにより明るさ知覚を推定するこ とができるとした。 小林 ${ }^{3)}$ は, 明るさ感は輝度と順応レベルによ り変化することを示した。また Bodmann ${ }^{4) 5}$ は, 明るさ感は輝度 と執務条件によることを示し，明るさ尺度を提案した。さらに Marks ${ }^{6) 7)}$ は順応レベルが低いほど, 周辺視は中心視より明るくみ えることを示した。 その他にも $\operatorname{Loe}^{8)}$ による視野内の平均輝度と 明るさ感の研究, 加藤ら ${ }^{9}$ による光の到来バランスを考慮した研 究，高ら ${ }^{10)}$ にる輝度のばらつきを考慮した空間の明るさ感に関 する研究など多くの明るさ感に関連する研究が行われてきてい る。照明学会においては, 二つの研究調査委員会を設置して明る

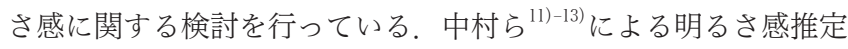
モデルは，空間を撮影した画像を輝度画像に変換し，それを用い て空間の明るさ感を評価している，空間の明るさ感の考え方とし て, 著者は「空間の明るさ感はその空間を眺めた際の視野内の輝 度分布によって決まる」としている。荻内ら ${ }^{14)}$ と石田ら ${ }^{15)}$ にる 明るさ感推定モデルは, 室内の輝度分布を算出（仮想輝度分布算 出）し，この仮想輝度分布と実測輝度分布から空間の明るさ感指 標を算出している，空間の明るさ感の考え方として，著者は「空 間の明るさ感はその空間に満ちている光の量に対する感覚であ る」としている。つまり空間の明るさ感の定式化は, 空間に満ち \begin{tabular}{l}
\hline 本論文の一部について, 第 6 回日中韓照明カンファレンスおよび平成25年度照明学 \\
会全国大会で綿貫將が発表した。
\end{tabular}
ている光量に対する感覚を物理量から推定することであるとして いる. 山口ら ${ }^{16)}$ による明るさ感推定モデルは, 明度の恒常性とい う視覚特性に着目し, 視対象の明るさを変化させたときの色の見 え方（色の見え方のモード）の違いを利用し，空間の明るさ感指 標を算出している，空間の明るさ感の考え方として，著者は「視 覚系で得られた輝度情報から視対象周辺での光量の認識と, 視対 象表面の反射率に相当する值の認識が空間の明るさ感と関係があ る」としている。ささらに空間の明るさ感の評価として「色モード 境界輝度という輝度の絶対值に置き換えることで, 空間の明るさ 感を定量的に扱うことができる」としている，さらに，色モード 境界輝度には加法性が成立することも明らかにし ${ }^{17)}$, 岩井ら ${ }^{18)}$ は, 明るさ感評価モデルである Feu を提案している。 しかし既存の推 定モデルは，輝度の範囲を限定するモデルや周辺視における明る さ知覚が反映していないモデルなど，それぞれ未解明領域が多い ことが現状であり，その精度が十分であるとはいえない。また， 中心視と周辺視における明るさ知覚特性に関する研究では, 古く は網膜感度の不均一性により, 周辺視と中心視では明るさ知覚量 が異なることが明らかにされている(7)7)。さに, 戴ら ${ }^{1920)}$ は周辺 視と中心視で明るさ知覚が異なる理由に関して, 周辺視ほど輝度 対比効果が強いためと推測している。しかしこれらの既往研究で は, 水平方向のみの網膜偏心度ごとの明るさ知覚特性を明らかに しており，鉛直方向や斜め方向など各方位における明るさ知覚特 性は明らかにされていない，空間の各位置の光源による明るさ知 覚特性が視野全体の明るさ感に及ぼす影響が明らかになれば，空 間全体の明るさ感を評価できると考えられる。本研究では，空間 全体の明るさ感は, 局所的なスポット光の明るさ知覚にある係数 を掛けて加算することで評価できるという仮説を立て，本論文で は光源一つが各方位に存在する場合の明るさ知覚特性を明らかに することを目的とする．

\section{2. 予備実験}

\section{1 実験方法}

本研究では被験者が自ら, 周辺視野域に提示された刺激光の輝 


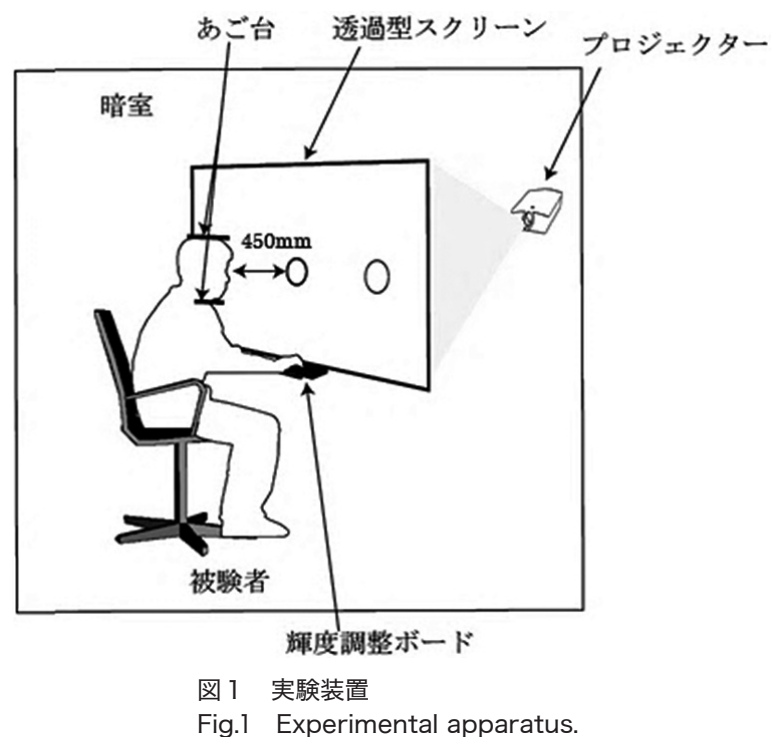

度を基準光の輝度と同等な明るさになるように調整する明るさ マッチング法を用いる。 そこで調整するテスト光の初期輝度を設 定するにあたり，視線方向の基準光の輝度より高い条件と低い条 件で実験を行い, 調整後のテスト光の輝度值を比較し, 刺激光の 初期輝度が明るさ知覚に与える影響について検討した。図 1 に実 験環境を示す。実験は暗室で行い, 透過型スクリーンにプロジェ ク夕を利用して刺激を提示し, 背景輝度を $1.0 \mathrm{~cd} / \mathrm{m}^{2}$ とした。また 観測距離を450mm とした。 スクリーンの中心に基準光を提示し, 周辺視野域にテスト光を提示した。 これらの光は白色, 直径 5 。 の円とした.テスト光の提示位置は基準光の水平右方向とし, 基 準光からテスト光までの距離（偏心度）は， $5^{\circ}$ から50とした。 また基準光の輝度である $\mathrm{L}_{\mathrm{m}}$ は, $20 \mathrm{~cd} / \mathrm{m}^{2}, 50 \mathrm{~cd} / \mathrm{m}^{2}$ の 2 種類とした. テスト光の初期輝度は, 基準光の輝度よりも高い条件（1.5倍） および低い条件 (3/5倍) とした。

被験者の注視点は基準光の中心部に固定し，テスト光の輝度を 基準光の輝度と等しい明るさとなるように調整した，被験者は20〜 25歳の視覚正常者 5 名である.

\section{2 実験手順}

本予備実験では，テスト光の初期輝度を，視線方向の基準光の 輝度より高い值と低い值に設定した 2 回の実験を行った。実験手 順を以下に示す。

(1) スクリーンの輝度に10分間順応する.

(2) 基準光の中心を固視する

（3）実験精度を高めるために，被験者内で明るさの感覚を覚える 時間を設け，10〜15回の練習を行う.

ただし練習回数は，被験者内において測定デー夕つまり明る さ知覚が安定する時を目安とした。

（4）基準光の明るさと等しい明るさとなるように，被験者自身が テスト光を調光する.ただし視線方向は(2)の状態を維持する.

(5) テスト光の偏心度をランダムに変化させ(2)〜(4)を繰り返し行 う.

（6）基準光の輝度を変え，(1)〜(5)を繰り返し行う.

本実験計画では，各実験条件を同一被験者で行う被験者内計 画を採用した。そこで被験者の疲労効果, 実験条件による順序 効果, 実験回数による練習効果を除去するために, 以下の手続 きを行った。疲労効果対策として，30４0分ごとに 5〜10分程 度の休息をとり，順序効果対策として(5)のように刺激提示位置 をランダム設定し, 練習効果対策として事前に(3)のように練習 時間を設けた。

\section{3 実験結果}

被験者 5 名の実験結果の平均值を図 2 および図 3 に示す。基準 光と等しい明るさに調整した時のテスト光の輝度を $\mathrm{L}_{\mathrm{t}}$ とし, 偏 心度と $\mathrm{L}_{\mathrm{t}}$ との関係を求めたものである。ここで, テスト光の初 期輝度が基準光の輝度より高い条件を条件 1 , 低い条件を条件 2 とした。図2 2 おび図 3 ょ，各偏心度における $\mathrm{L}_{\mathrm{t}}$ 值に初期輝 度の違いによる大きな影響はみられない。 そこで偏心度と各条件 (テスト光初期輝度）による $\mathrm{L}_{\mathrm{t}}$ 值への影響の有無を調べるため, テスト光の初期輝度条件と偏心度条件を要因として 2 元配置の分 散分析を行った。その結果, テスト光の初期輝度の主効果は有意 でなかった。またテスト光の初期輝度と偏心度による交互作用は 有意でなかった。これらの結果より，テスト光の初期輝度による 実験結果 $\left(\mathrm{L}_{\mathrm{t}}\right.$ 值 $)$ への影響は小さいことが示された。よって本実 験でのテスト光の初期輝度は, 基準光の輝度よりも低い条件で実 験を行うこととした。

\section{3. 本実験}

\section{1 実験方法}

実験環境は予備実験と同様に設定し, 背景輝度を $0.6 \mathrm{~cd} / \mathrm{m}^{2}$ とし た。図4にスクリーンの条件を示す，中心に基準光を提示し，周 辺視野域にテスト光を提示した。これらの光は白色, 直径 $5{ }^{\circ}$ の 円とした．図5にテスト光提示位置を示す。テスト光の提示方向 は，基準光の水平右方向，鉛直上方向および鉛直下方向， $45^{\circ}$ 方 向および $315^{\circ}$ 方向とした.また基準光からテスト光までの距離(偏

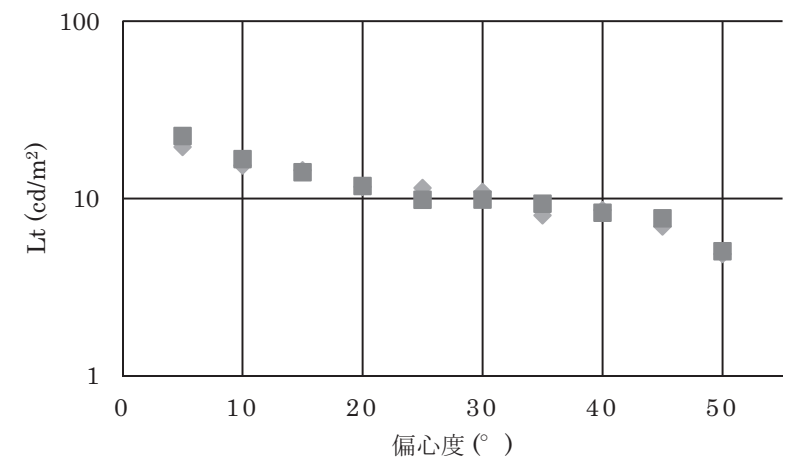

図 2 偏心度と $\mathrm{L}_{t}$ との関係（基準光輝度 $20 \mathrm{~cd} / \mathrm{m}^{2}$ )。 : 条件 1 （テスト光 初期輝度 $12 \mathrm{~cd} / \mathrm{m}^{2}$ ), 口: 条件 2（テスト光初期輝度 $30 \mathrm{~cd} / \mathrm{m}^{2}$ )

Fig.2 Relation between the presentation position and $L_{t}$ (The luminance of matching light is $20 \mathrm{~cd} / \mathrm{m}^{2}$ ). $:$ conditionl (The initial luminance of test light is $12 \mathrm{~cd} / \mathrm{m}^{2}$ ), $\mathbf{\square}:$ condition2 (The initial luminance of test light is $30 \mathrm{~cd} / \mathrm{m}^{2}$ ).

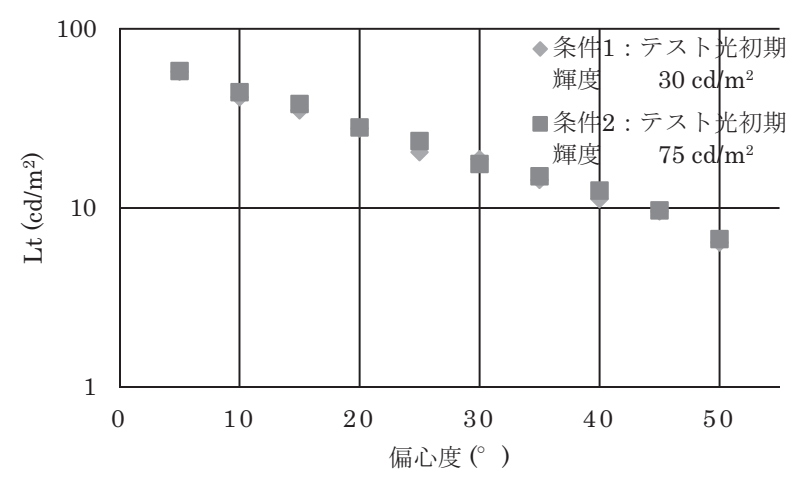

図 3 偏心度と $L_{t}$ との関係（基準光輝度 $50 \mathrm{~cd} / \mathrm{m}^{2}$ )。 : 条件 1 （テスト光 初期輝度 $30 \mathrm{~cd} / \mathrm{m}^{2}$ ), ロ : 条件 2（テスト光初期輝度 $75 \mathrm{~cd} / \mathrm{m}^{2}$ )

Fig.3 Relation between the presentation position and $L_{t}$ (The luminance of matching light is $50 \mathrm{~cd} / \mathrm{m}^{2}$ ). $\bullet$ : conditionl (The initial luminance of test light is $30 \mathrm{~cd} / \mathrm{m}^{2}$ ), $\mathbf{a}$ : condition2 (The initial luminance of test light is $75 \mathrm{~cd} / \mathrm{m}^{2}$ ). 


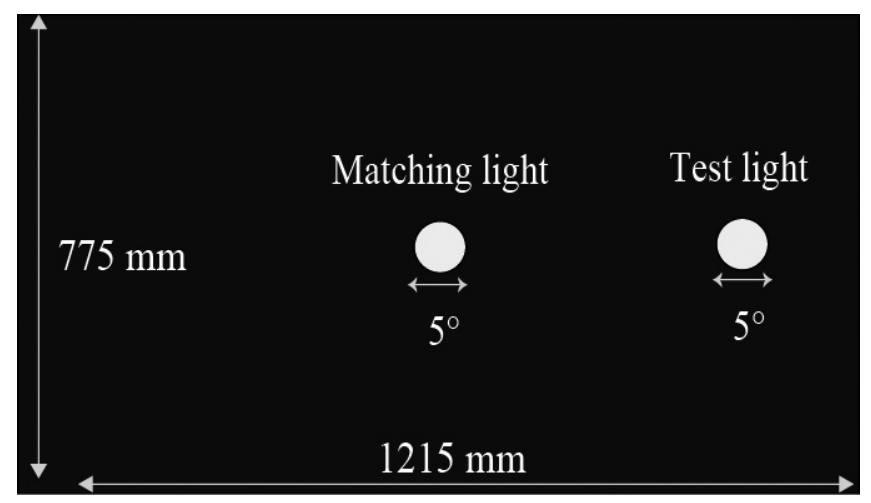

図4 スクリーンの条件

Fig.4 Screen condition.

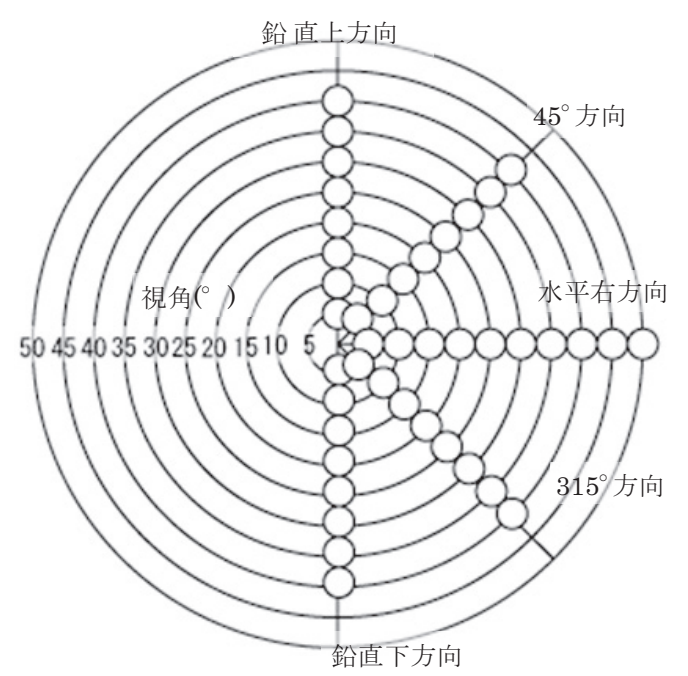

図 5 テスト光提示位置

Fig.5 The presentation position of test light.

心度) は, $5^{\circ}$ から $40^{\circ}$ とした。だし水平右方向は $5^{\circ}$ から $50^{\circ}$ と した. 基準光の輝度 $\mathrm{L}_{\mathrm{m}}$ は20, $50,100,200 \mathrm{~cd} / \mathrm{m}^{2}$ の 4 条件とした. ただし本実験ではプロジェクタとスクリーンを用いて実験を行う ため, 㛜密には実際に提示した輝度值が異なる。表 1 に実際に提 示した基準光の輝度 $\mathrm{L}_{\mathrm{m}}$ およびそれに対応するテスト光の初期輝 度を示す，予備実験の結果からテスト光の初期輝度は，基準光の 輝度よりも低い条件（3/5倍）を用いた。

被験者の注視点は基準光の中心部に固定し，テスト光の輝度を 基準光の輝度と等しい明るさとなるように調整した，被験者は20〜 25歳の視覚正常者10名である.

\section{2 実験手順}

本実験目的である，各視野位置における明るさ知覚を求めるた めには, 微小な明るさ知覚の違いを測定する必要がある。この微 小な明るさ知覚を評価する手段として, 調整法を用いたマッチン グ法が最も精度が高いという報告がある ${ }^{6)}$ 。そこで本実験では， 予備実験と同様に, 被験者自身が輝度を自由に変化させることが できる調整法を用いて，テスト光の明るさを基準光の明るさと等

\section{表 1 基準光の輝度 $L_{m}$ および対応するテスト光の初期輝度}

Table 1 The luminance of matching light and the initial luminance of test light.

\begin{tabular}{|c|c|}
\hline $\begin{array}{c}\text { 基準光輝度 } \\
\mathrm{L}_{\mathrm{m}}\left(\mathrm{cd} / \mathrm{m}^{2}\right)\end{array}$ & $\begin{array}{c}\text { テスト光初期輝度 } \\
\left(\mathrm{cd} / \mathrm{m}^{2}\right)\end{array}$ \\
\hline 20.49 & 11.9 \\
\hline 51.05 & 30.6 \\
\hline 100.3 & 61.49 \\
\hline 202 & 121.2 \\
\hline
\end{tabular}

しくするマッチング実験を行った。実験手順を以下に示す。

(1) スクリーンの輝度に10分間順応する。

(2) 基準光の中心を固視する.

（3）実験精度を高めるために，被験者内で明るさの感覚を覚える 時間を設け，10〜15回の練習を行う.

ただし練習回数は，被験者内において測定データつまり明る さ知覚が安定する時を目安とした。

（4）基準光の明るさと等しい明るさとなるように，被験者自身が テスト光を調光する.ただし視線方向は(2)の状態を維持する.

(5) テスト光の提示方向掞よび偏心度をランダムに変化させ(2)〜 (4)を繰り返し行う.

（6）基準光の輝度を変え，(1)〜(5)を繰り返し行う。

\section{4. 実験結果と考察}

被験者 10 名の実験結果の平均值の一例を図 6 に示す。基準光と 等しい明るさに調整した時のテスト光の輝度を $\mathrm{L}_{\mathrm{t}}$ とし，偏心度 と $\mathrm{L}_{\mathrm{t}}$ との関係を求めたものである。 な打図中に示す誤差棒は被 験者間の標準誤差を表す。水平右方向では偏心度が大きくなるに したがって， $\mathrm{L}_{\mathrm{t}}$ が小さくなる。つまり視線方向から遠ざかるにし たがって, 基準光よりも低い輝度で等しい明るさを感じるといえ る. 他の提示方向についても同様の傾向が示された。この結果は, 視線方向から遠ざかるにしたがって輝度対比効果が強くなり, 視 線方向よりも明るく感じる現象 ${ }^{7719)}$ と一致している。これは既往 研究と同様に, 本実験のように背景輝度が低い場合には輝度対比 効果が強くなり, 周辺視の方が中心視よりも明るく感じたと考え られる。戴ら ${ }^{19)}$ は周辺視ほど輝度対比効果が強くなることを明ら かにしているが，本実験では背景輝度と基準光の輝度比は33以上 となっており, 戴らの既往研究よりも輝度比は大きいため, 周辺 視での輝度対比効果はより強く現れていると考えられる。

各提示方向における偏心度と $\mathrm{L}_{\mathrm{m}} / \mathrm{L}_{\mathrm{t}}$ との関係を図 7 図 11 に示 す。なお $\mathrm{L}_{\mathrm{m}} / \mathrm{L}_{\mathrm{t}}$ とは，基準光の輝度とテスト光の輝度の比，すな

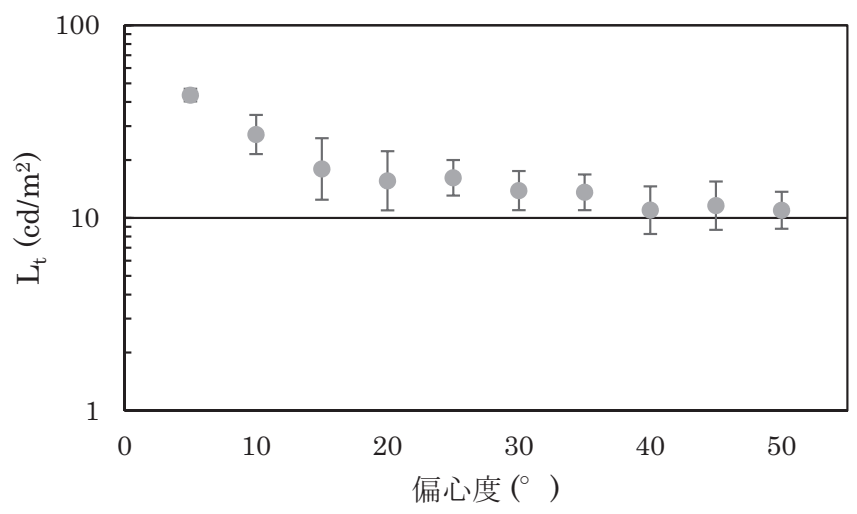

図 6 偏心度と $L_{t}$ との関係 (水平右方向, $L_{m}: 50 \mathrm{~cd} / \mathrm{m}^{2}$ )

Fig.6 Relation between the presentation position and $L_{t}$ (Horizontal direction, $\left.L_{m}: 50 \mathrm{~cd} / \mathrm{m}^{2}\right)$.

$\operatorname{Lm}\left(\mathrm{cd} / \mathrm{m}^{2}\right)$

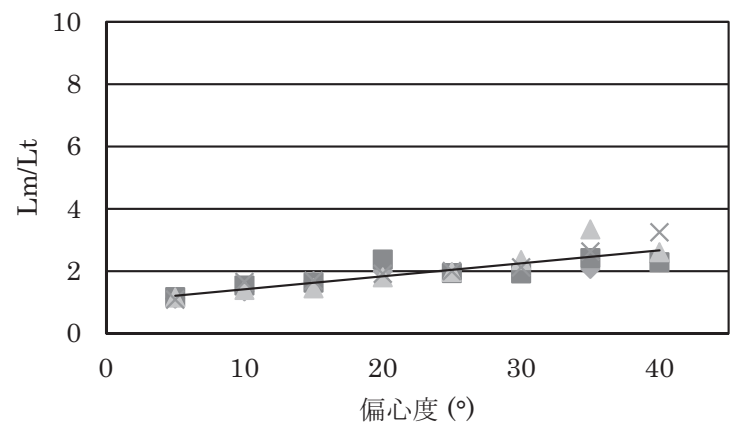

$\checkmark 20$

50

$\triangle 100$

$\times 200$

図 7 鉛直上方向における偏心度と $L_{m} / L_{t}$ との関係

Fig.7 Relation between the presentation position and $L_{m} / L_{t}$ (Vertical upper direction). 
$\mathrm{Lm}\left(\mathrm{cd} / \mathrm{m}^{2}\right)$

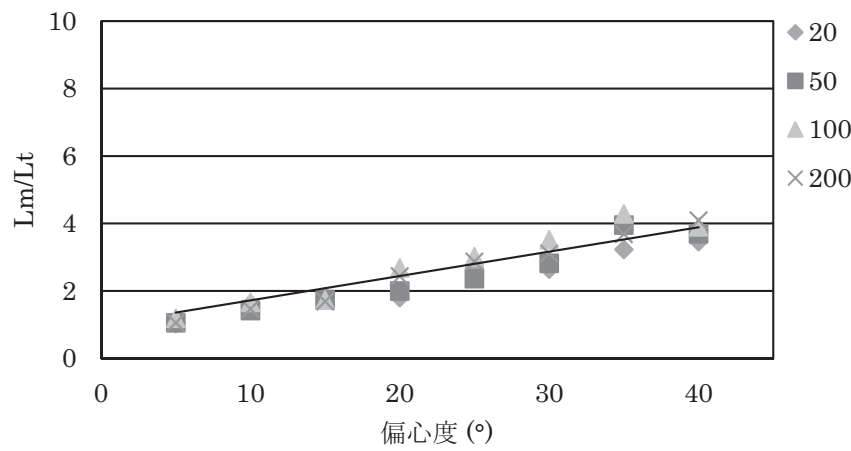

図 $845^{\circ}$ 方向における偏心度と $L_{m} / L_{t}$ との関係

Fig.8 Relation between the presentation position and $L_{m} / L_{t}$ (Direction of 45 degrees from the horizontal direction).

$\operatorname{Lm}\left(\mathrm{cd} / \mathrm{m}^{2}\right)$

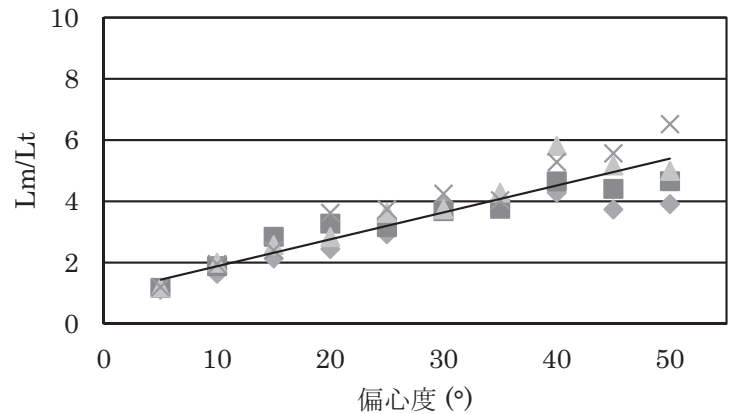

$\diamond 20$

50

$\triangle 100$

$\times 200$

図 9 水平右方向における偏心度と $L_{m} / L_{t}$ との関係

Fig.9 Relation between the presentation position and $L_{m} / L_{t}$ (Horizontal right direction).

$\operatorname{Lm}\left(\mathrm{cd} / \mathrm{m}^{2}\right)$

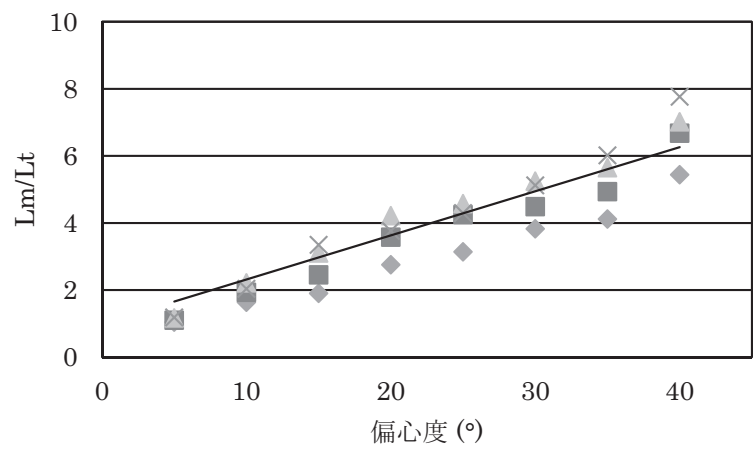

$\diamond 20$

50

$\triangle 100$

$\times 200$

図10 $315^{\circ}$ 方向における偏心度と $L_{m} / L_{t}$ との関係

Fig.10 Relation between the presentation position and $L_{m} / L_{t}$ (Direction of 315 degrees from the horizontal direction).

$\operatorname{Lm}\left(\mathrm{cd} / \mathrm{m}^{2}\right)$

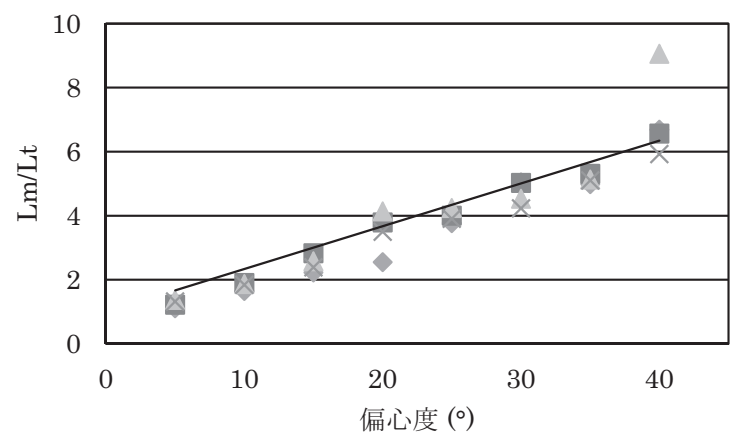

$\checkmark 20$

50

$\triangle 100$

$\times 200$

図11 鉛直下方向における偏心度と $L_{m} / L_{t}$ との関係

Fig.11 Relation between the presentation position and $L_{m} / L_{t}$ (Vertical lower direction).
わち基準光と等しい明るさを得るために何倍の輝度が必要かを示 す指標である。 また各提示方向における偏心度と $\mathrm{L}_{\mathrm{m}} / \mathrm{L}_{\mathrm{t}}$ との寄与 率 $\mathrm{R}^{2} お$ よび各提示方向における傾きを表 2 に示す。

図7〜図11より $\mathrm{L}_{\mathrm{m}} / \mathrm{L}_{\mathrm{t}}$ は, 偏心度が大きくなるにしたがって, 上昇する傾向が示された。一方，偏心度が大きくなると，基準光 輝度 $\mathrm{L}_{\mathrm{m}}$ の違いにより $\mathrm{L}_{\mathrm{m}} / \mathrm{L}_{\mathrm{t}}$ の值に差が生じるが, 表 2 より寄与 率 $\mathrm{R}^{2}$ は， 0.75 以上と強い相関を示し，線形回㷌が可能であること が示された。また，傾きの值は提示方向により異なり，鉛直下方 向拉よ゙ $315^{\circ}$ 方向では 0.15 と最も高い值を示した。つまり偏心度 の増加量に対して $\mathrm{L}_{\mathrm{m}} / \mathrm{L}_{\mathrm{t}}$ の増加量が大きいことを示している. こ れらの結果から, 周辺視領域での偏心度と $\mathrm{L}_{\mathrm{m}} / \mathrm{L}_{\mathrm{t}}$ は線形関係であ り，提示方向によって傾き（偏心度と $\mathrm{L}_{\mathrm{m}} / \mathrm{L}_{\mathrm{t}}$ の割合）が変化する ことが明らかになった。

ここで, 提示方向による $\mathrm{L}_{\mathrm{m}} / \mathrm{L}_{\mathrm{t}}$ 值への影響の有無を調べるため, 偏心度 (8 水準) および提示方向 ( 5 水準), $\mathrm{L}_{\mathrm{m}}$ ( 4 水準) の 3 要因に対して, 多元配置の分散分析を行った。その結果，偏心度 の主効果 $(\mathrm{P}<0.01)$ および提示方向の主効果 $(\mathrm{P}<0.05)$ が有意であっ たが，基準光輝度 $\mathrm{L}_{\mathrm{m}}$ の主効果は有意でなかった。また「偏心度 $\times$ 提示方向」の交互作用 $(\mathrm{P}<0.01)$ が有意であった。このほかの 交互作用は有意でなかった。そこで, 提示方向の各水準における 偏心度の単純主効果の検定をした結果, 鉛直上方向における偏心 度の単純主効果は有意でなかった。つまり, 偏心度の効果と提示 方向による効果は分離して考えることができないことが示唆され た。

ここで, 図12に $\mathrm{L}_{\mathrm{m}} / \mathrm{L}_{\mathrm{t}}$ 曲線を示す。分散分析の結果より, $\mathrm{L}_{\mathrm{m}}$ に よる $\mathrm{L}_{\mathrm{m}} / \mathrm{L}_{\mathrm{t}}$ への影響が小さいことが示されたため, $\mathrm{L}_{\mathrm{m}} 4$ 条件の $\mathrm{L}_{\mathrm{m}} / \mathrm{L}_{\mathrm{t}}$ の平均值を用いた。 また左側の各視野位置は右側と対称と みなした。図12の縦軸および横軸は $\mathrm{L}_{\mathrm{m}} / \mathrm{L}_{\mathrm{t}}$ であり, また横軸から の傾きは本実験での提示方向を意味している．鉛直上方向と鉛直 下方向を比較すると, 同一偏心度条件における $\mathrm{L}_{\mathrm{m}} / \mathrm{L}_{\mathrm{t}}$ の值差が明 瞭である。これは提示方向によって傾きが異なることが影響して いる，つまり，傾きの值が 0.15 と最も大きかった鉛直下方向およ び $315^{\circ}$ 方向では, 偏心度の増加量に対して $\mathrm{L}_{\mathrm{m}} / \mathrm{L}_{\mathrm{t}}$ の増加量が大き い. すなわち提示方向によって偏心度による $\mathrm{L}_{\mathrm{m}} / \mathrm{L}_{\mathrm{t}}$ への効果の違

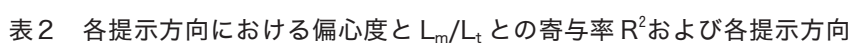
における傾き

Table 2 Contribution rate and slope between the presentation position and brightness sensitivity in each direction.

\begin{tabular}{|c|c|c|c|c|c|}
\hline & \multicolumn{5}{|c|}{ 提示方向 } \\
\cline { 2 - 6 } & 鉛直上 & $45^{\circ}$ & 水平右 & $315^{\circ}$ & 鉛直下 \\
\hline 寄与率 $\mathrm{R}^{2}$ & 0.75 & 0.91 & 0.84 & 0.88 & 0.89 \\
\hline 傾き & 0.041 & 0.082 & 0.086 & 0.15 & 0.15 \\
\hline
\end{tabular}

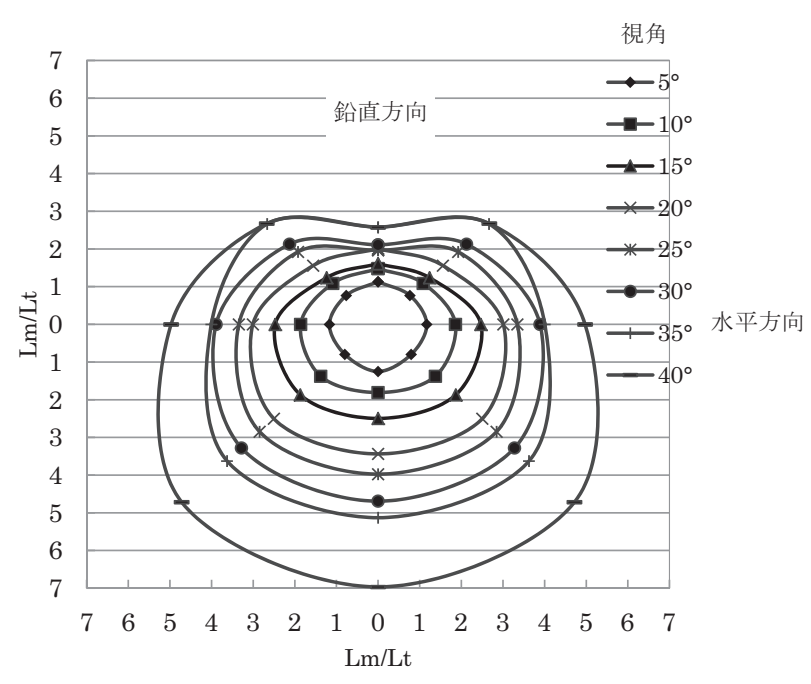

図12 $L_{m} / L_{t}$ 曲線

Fig.12 $L_{m} / L_{t}$ curve. 
いが示された。

次に各提示方向における $\mathrm{L}_{\mathrm{m}} / \mathrm{L}_{\mathrm{t}}$ に注目すると, 水平右方向では, 偏心度が大きくなるにしたがって, $\mathrm{L}_{\mathrm{m}} / \mathrm{L}_{\mathrm{t}}$ が上昇する。鉛直下方 向では，偏心度が大きくなるにつれ， $\mathrm{L}_{\mathrm{m}} / \mathrm{L}_{\mathrm{t}}$ が上昇する。特に偏 心度が $20^{\circ}$ 以上となると他の方向と比べ $\mathrm{L}_{\mathrm{m}} / \mathrm{L}_{\mathrm{t}}$ が高くなる傾向が 示された，鉛直上方向は偏心度に関係なく，他の方向と比べ $\mathrm{L}_{\mathrm{m}}$ ' $\mathrm{L}_{\mathrm{t}}$ が低くなる傾向が示され，偏心度による影響を受けにくい. $45^{\circ}$ 方向および $315^{\circ}$ 方向は, それぞれ鉛直方向と水平方向の中間 的特性が示された。

既往研究 ${ }^{719)}$ では, 水平方向の偏心度により明るさ知覚特性が 異なることが明らかにされているが, 本研究においては偏心度と 提示方向を組み合わせることにより，全方向での明るさ知覚特性 を明らかにした， $\mathrm{L}_{\mathrm{m}} / \mathrm{L}_{\mathrm{t}}$ 曲線は視野位置によって明るさ知覚がど の程度異なるのかを全方位において示す指標である。

\section{5. まとめ}

本研究では, 各視野位置にある光源が明るさ知覚特性に及ぼす 影響ついて検討した，その結果をまとめると以下のようになる。

（1）基準光輝度 $\mathrm{L}_{\mathrm{m}}$ による $\mathrm{L}_{\mathrm{m}} / \mathrm{L}_{\mathrm{t}}$ への影響は小さい.

（2）偏心度が大きくなるにつれて, $\mathrm{L}_{\mathrm{m}} / \mathrm{L}_{\mathrm{t}}$ が上昇し, 偏心度と $\mathrm{L}_{\mathrm{m}} /$ $\mathrm{L}_{\mathrm{t}}$ は線形関係である。

（3）各提示方向により明るさ知覚特性に違いが示され，特に鉛直 下方向では, 偏心度が $20^{\circ}$ 以上の条件で他の方向と比べ $\mathrm{L}_{\mathrm{m}} / \mathrm{L}_{\mathrm{t}}$ が高い

本研究の実験条件では，背景輝度を $0.6 \mathrm{~cd} / \mathrm{m}^{2}$ ，すなわち薄明視 下での $\mathrm{L}_{\mathrm{m}} / \mathrm{L}_{\mathrm{t}}$ を求めている。 そのため背景輝度による $\mathrm{L}_{\mathrm{m}} / \mathrm{L}_{\mathrm{t}}$ への 影響を検討する必要がある。さらに本研究ではテスト光を特定の 視野位置に一つ提示した条件で実験を行い, その視野位置の $\mathrm{L}_{\mathrm{m}} /$ $\mathrm{L}_{\mathrm{t}}$ を明らかにすることができたが, テスト光を複数個隣接して提 示した条件での実験と本実験結果を比較し, より複雑な輝度対比 効果について検討する必要がある.

\section{参考文献}

(1) Stevens,S.S. : On the psychophysical law. Psychological Review, 64-3, pp.153-181 (1957).

(2) Stevens, S.S. : Duration, luminance, and the brightness exponent. Perception \& Psychophysics, 1, pp.96-100 (1966).

（3）小林朝人：明るさの知覚尺度, 日本建築学会論文集, 178, pp.83-90 (1970).

(4) Bodmann,H.M., Huabner,P. and Marsden,A.m. : A unified relationship between brightness luminance, Proc.CIE 19th session, CIE Paris, p.99 (1980).

(5) Bodmann,H.W. and La Toison,M. : Predicted brightness luminance phenomena. Lighting Research and Technology, 26-3, pp.135-143 (1994).

(6) Marks,L.E. : Brightness as a function of retinal locus in the light adapted eye. Vision Research, 8, pp.525-535 (1968).

(7) Marks.L.E. : Brightness and retinal locus : Effects of target size and spectral composition, Perception \& Psychophysics, 9, pp.26-30 (1971).

(8) Loe,D.L, Mansfield,K.P. and Rowlands,E. : Appearance of lit environment and its relevance in lighting design Experiment study, Light.Res.Technol., 26-3, pp.119-133 (1994).

（9）加藤未佳, 太田裕司, 羽入敏樹, 関口克明 : 光の到来バ ランスを考慮した空間の明るさ感の評価，日本建築学会 環境系 論文集，568，pp.17-23 (2003)

(10) 高乗佑, 古賀誉章, 魯斌, 平手小太郎, 水野将明, 鈴木 直行 : 輝度のばらつきを考慮した空間の明るさ感の予測 に関する基礎研究, 照学誌, 97-8, pp.429-435 (2013).
（11） 中村芳樹, 江川光徳：均一背景を持つ視対象の明るさ知 覚一輝度の対比を考慮した明るさ知覚に関する研究（そ の 1 ), 照学誌, 88-2, pp.77-84 (2004).

(12) 中村芳樹, 江川光徳 : コントラスト・プロファイルを用 いた明るさ知覚の予測一輝度の対比を考慮した明るさ知 覚に関する研究 (その2), 照学誌, 89-5, pp.230-235 (2005).

(13) 中村芳樹：ウェーブレットを用いた輝度画像と明るさ画 像の双方向変換一輝度対比を考慮した明るさ知覚に関す る研究 (その 3 ), 照学誌, 90-2, pp.97-101 (2006).

(14) 荻内康雄, 石田泰一郎：仮想輝度分布法による実大空間 の明るさ感推定に関する検討，日本建築学会環境系論文 集, 583, pp.7-14 (2004).

(15) 石田泰一郎, 荻内康雄 : 空間の明るさ感の心理的決定要 因一光源の強さ感と空間の光量感, 照学誌, 84-8A, pp.473-479 (2000).

(16) 山口秀樹, 篠田博之：色モード境界輝度による空間の明 るさ感評価, 照学誌, 91-5, pp.266-271 (2007).

(17) 山口秀樹, 篠田博之 : 複雑な照明環境における色モード 境界輝度の分布と加法性, 照学誌, 90-8A, pp.504-512 (2006)

(18) 岩井彌，井口雅行：空間の明るさ感指標「Feu」による快 適な空間創りのための新しい照明評価手法, 松下テクニ カルジャーナル, 53-2, pp.64-66 (2008).

(19) 戴倩穎, 中村芳樹：周辺視野における明るさ知覚に関す る研究一周辺視位置と輝度比の効果一, 照学誌, 96-11, pp.739-746 (2012).

(20) 戴倩穎, 中村芳樹 : 視野内中心領域が周辺領域の明るさ 知覚に及ぼす効果，照学誌，96-5, pp.286-292 (2012).

（受付日2014年 8 月29日／採録日2015年 2 月26日）

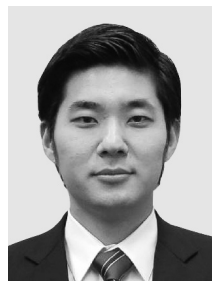

綿貫＼cjkstart將（正会員）

株式会社日建設計

干102-8117 東京都千代田区飯田橋2-18-3

1989年生まれ。2012年 3 月芝浦工業大学工学部 電気工学科卒業，2014年 3 月同大学院修士課程 修了。2014年 4 月株式会社日建設計に入社.

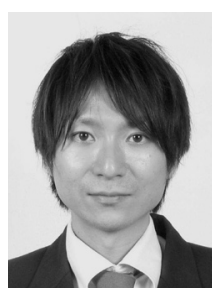

高橋 宏（正会員）

神奈川工科大学工学部電気電子情報工学科 干243-0292 神奈川県厚木市下荻野1030 1978年生まれ。2001年 3 月芝浦工業大学工学部 電気工学科卒業, 同大学院修士・博士課程修了. 芝浦工業大学マレーシア JAD プログラム助教などを経て, 2012 年より神奈川工科大学工学部助教. 博士 (工学). 感性工学会会員.

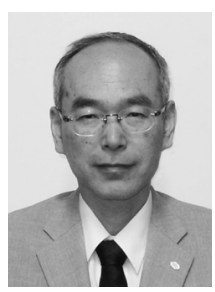

\section{入倉 隆 (専門会員)}

芝浦工業大学工学部電気工学科

干135-8548 東京都江東区豊洲3-7-5

1956年生まれ。1979年 3 月早稲田大学理工学部 電気工学科卒, 運輸省交通安全公害研究所など を経て, 芝浦工業大学工学部教授. 博士 (工学). 感性工学会, 日本視覚学会, 日本光学会会員. 